\title{
The Role of the School in Developing Student Development Tasks
}

\author{
Jumadil Saputra ${ }^{1}$, Agung Prabowo ${ }^{2 *}$ \\ ${ }^{1}$ Faculty of Business, Economics and Social Development, Universiti Malaysia Terengganu, 21030 Kuala Nerus, Terengganu, \\ Malaysia \\ ${ }^{2}$ Department of Mathematics, Faculty of Mathematics and Natural Sciences, Universitas Jenderal Soedirman, Indonesia
}

*Corresponding author email: agung.prabowo@unsoed.ac.id,agung_nghp@yahoo.com

\begin{abstract}
The development of student life is the responsibility of the parents who gave birth to it. If we empathize and can live the dynamics of a student's psychic life, we as adults will regret having treated a child or student incorrectly. This shows that we need to know about the world of children or students both at home and at school. So that we know how necessary parents, teachers, and anyone who is engaged in the field of education understand the stages and tasks of child or student development. In this study only focused on the role of educators and teachers for student development. The purpose of this paper discusses the school efforts to achieve student development into a better person. The method used in this research is literature studies with a focus on student development. The results show the role of the school is very important for the development of students to face the world of work in the future. The explanation presented in this paper, still seems to be dominated by the opinions or findings of experts from the West. Therefore, for further research, it is necessary to conduct a more comprehensive study, both textually and contextually.
\end{abstract}

Keywords: Role of school, development, students, education

\section{Introduction}

Development can be interpreted as the progressive and continuous change in the organism from birth to death (Marlina, 2021). The purpose of developmental research is to provide an overview of the behavior of children or students and identify the causal factors and processes that give birth to behavioral changes from one development to the next. Developmental psychologists study these behavioral changes in all individual life cycles from conception to death, although many of their efforts have focused on adolescence. In recent years, research on development has been directed towards issues related to adult development giving birth to developmental psychology throughout the life span.

The task of development is a task that arises at a certain period in the life span of the individual, which if the task can be successfully completed will bring happiness and success in completing the next task, while if it fails it will cause unhappiness in the individual concerned, causing community rejection, and difficulties in completing the next tasks. These developmental tasks are related to attitudes, behaviors or skills that should be possessed by the individual, according to their age or phase of development. A person's ability to find resources and ways to obtain his needs, and complete developmental tasks is a key signal for the speed of development. Efforts to explore and learn are essential to moving toward self-realization (Darling-Hammond, et al. 2020).

Factors that affect the development of children or students one of them is the developmental environment. A child's or a student's developmental environment is a whole physical or social phenomenon (event, situation, or condition) that affects or influences a student's development (Chapman, 2016). Student development environments include family, school, peer group, and community environments (James et al., 2003). This paper focuses on the school environment. The School is a formal educational institution that systematically carries out guidance, teaching, and training programs in order to help students to be able to develop their potential, both regarding moral-spiritual, intellectual, emotional and social aspects (Woolfolk, 2017).

Michael Rutter in (James et al., 2003) defines an effective school as one that advances, enhances, or develops academic achievement, social performance, one-way mannerisms, a positive attitude toward learning, low numbers of student absenteeism, and provides skills that enable students to work. Effective schools are strongly supported by the 
quality of teachers, both in terms of personal characteristics and competence. The personal characteristics and competencies of these teachers greatly affect the quality of the classroom climate, the learning process in the classroom, or the teacher-student relationship in the classroom, which in turn will also affect the success of student learning (Ellis \& Childs, 2019)..

Regarding the role of schools in developing children's personalities, Hurlock (Saepuddin, 2019) suggested that school is a determining factor for the development of children's personalities (students), both in the way of thinking, behaving and how to behave. Schools act as family substitution and teacher substitution parents. There are several reasons why school plays a meaningful role for the development of the child's personality, namely (a) students must be present in school, (b) the school gives influence to children early along with the development of "self-concept", (c) children spend more time in school than anywhere else outside the home, (d) school provides opportunities for students to achieve success, and (e) schools give children the first opportunity to assess themselves and their abilities realistically (Barac \& Bialystok, 2012).

Developmental tasks during school include learning to acquire physical skills to play games, learning to form a healthy attitude towards oneself as a biological being, learning to get along with peers, learning to play roles according to gender, learning basic skills in reading, writing and arithmetic, learning to develop everyday concepts, developing conscience, learning to gain personal freedom, developing positive attitudes towards social groups and institutions (James et al., 2003). As for the developmental tasks of adolescents as follows:
a) accepting their own physicality along with its diversity of qualities,
b) achieving emotional independence from parents or authority figures,
c) developing interpersonal communication skills and learning to get along with peers or other people, both individually and group,
d) finding a model human being as their identity,
e) accepting themselves and having confidence in their own abilities,
f) strengthening self-control on the basis of a value scale, principles or philosophy of life,
g) being able to leave childish reactions and adjustments.

\section{Materials and Methods}

The object of research in this paper is students or children aged 6 to 21 years. The research method used is a method of observation and literature studies from several reference sources to other reference sources and then analyzed. There are three theories or approaches to development, namely approaches to cognitive development, learning or environment, and ethological (Ellis \& Childs, 2019). Then, the emergence of developmental tasks stems from the following factors
a) physical maturity,
b) cultural demands of society,
c) demands from the individual's own impulses and ideals,
d) demands for religious norms.

\section{Results and Discussion}

The school has an important role or responsibility in helping students achieve their developmental tasks. In connection with that, the school should strive to create a conducive atmosphere or conditions that can facilitate students (who are teenagers) to achieve their development. The tasks of adolescent development concern aspects of maturity in social interaction, personal maturity, maturity in achieving philosophy of life, and maturity in believing and fearing God (Rudd, 2019). The achievement of student developmental tasks is divided into two, namely through peer groups and independent independence.

\subsection{Achievement of Developmental Tasks Through Peer Groups}

Peers play an important role for teenagers. Teens often put peers in priority positions when compared to parents, or teachers in declaring loyalty. In a fast-paced society, there are often disputes or misunderstandings between adolescent peer groups with parents, teachers and other people with authority (Knapp, 1987). However, if this situation can be handled wisely by adults, then the experience of adolescents in the peer group is very useful to achieve an attitude of independence and maturity of interpersonal relationships in a mature manner. In other words, in this peer group, adolescents can complete developmental tasks:
a) achieve mature new relationships with peers, both men and women
b) achieve social roles as men and women

The school's efforts in order to help students achieve both developmental tasks are

a) provide teaching or guidance on social skills 
b) provide opportunities for students to be active in group activities

c) teaching or guiding students about democratic living or making friends in a healthy manner

d) with students discussing the issue of the social role of men or women in society

e) encourage students to want to read literature that contains the role of men or women

f) assign students to observe social life as a discussion in discussions with teachers

\subsection{Achievement of the Task of Personal Independence Development}

Adolescence is a period of development towards autonomy or personal independence. To achieve this aspect of development, adolescents must be able to complete the following developmental tasks.
a) accept his physical state and utilize it effectively
b) achieving emotional independence from parents or other adults
c) achieving guarantees of economic independence
d) choosing and preparing for a job
e) preparing for marriage and family life
f) develop the intellectual concepts and skills necessary for competence as a citizen

In order to help adolescents, achieve the above developmental tasks, the school can facilitate them with the following efforts:
a) Through biology, health and sports lessons, or guidance services, subject teachers or guidance teachers can provide explanations of adolescent physical growth and change, including aspects of diversity.
b) Help students develop their appreciative attitude towards their posture, or their self-condition (their strengths and weaknesses).
c) Provide facilities for student activities in sports, arts, or other skills
d) Create a school atmosphere conducive to the emotional development of students in a mature manner (maintaining interpersonal relationships, especially between teachers- students, which are warm, understanding and accepting).

e) Provide information to students on how to deal with healthy frustration or stress

f) Provide opportunities for students (during the teaching-learning process) to ask questions or opinions

g) Provide guidance to students on ways to solve problems or make decisions.

h) Help students develop their self-confidence

i) Develop the appreciative attitude of students towards the school, that the school besides the place to study is also an investment in its future.

j) Develop students' attitudes and abilities to be self-employed

k) Through the process of teaching-learning or special guidance, teachers develop a spirited attitude or positive habits of students to learn

1) Develop students' positive attitude towards the world of work

m) Provide information about the world of work (requirements, type, physical environment, sociopsychological atmosphere, place, welfare assurance, and job prospects)

n) Help students on how to choose a job that is in complete with their interests and abilities

o) Discuss or brain storming about various problems or issues of juvenile delinquency, both regarding the type (fight, liquor, AIDS, promiscuity, and ecstasy), the factors of the cause, impact and how to overcome it.

In the last, the development of faith and piety in God must also be considered. This developmental task is related to the fact of man as a creature of God who has a sacred duty to worship God. In adolescence, the values of faith and piety must be implemented in everyday life. The achievement of this developmental task, in each adolescent seems to be heterogeneous. In order to assist students in strengthening their faith and piety, the school makes the following efforts.
a) School leaders, teachers and other school personnel must equally have concern for religious education programs or the cultivation of religious values in schools
b) Religious teachers at least have a good personality, understanding and professional skills, as well as the
c) Teachers insert religious values into the subjects they teach, so that students have a positive appreciation of religious values
d) The school provides a means of worship as a sufficient spiritual laboratory
e) Organize spiritual extracurricular activities, religious lectures or religious discussions on a regular basis
f) Cooperate with the parents of students in guiding the student's faith and piety. 
In relation to efforts to develop the religious nature of students, schools, especially in this case religious teachers, have a very important role in developing insight into understanding, habituation to practice worship or noble character and an appreciative attitude towards religious teachings. In order to carry out this task, religious teachers are required to have the following characteristics: In relation to efforts to develop the religious nature of students, schools, especially in this case religious teachers, have a very important role in developing insight into understanding, habituation to practice worship or noble character and an appreciative attitude towards religious teachings. In order to carry out this task, religious teachers are required to have the following characteristics:

a) Noble personality such as honest, responsible, committed to the task, disciplined in work, creative, and respect for students

b) Mastering disciplines in the Field of Religious Education Studies. Religious teachers have an adequate understanding of the field of study being taught, at least the materials contained in the curriculum

c) Understand other relevant sciences or support their ability to manage teaching and learning processes, such as educational psychology, guidance and counseling, teaching methodologies, educational administration, evaluation techniques and religious psychology. Besides, it is also necessary to understand the sciences that support the expansion of insight in explaining subject matter to students, such as sociology, anthropology, population and health.

\section{Conclussion}

In this paper, a study about the role of school in student development task. Development can be interpreted as the progressive and continuous change in the organism from birth to death. The purpose of developmental research is to provide an overview of the behavior of children or students. This paper focuses on the impact of the school environment on the development of a child or student. The School is a formal educational institution that systematically carries out guidance, teaching, and training programs. Adolescence is a period of development towards autonomy or personal independence. The tasks of adolescent development concern aspects of maturity in social interaction, personal maturity, and maturity in achieving philosophy of life. The achievement of student developmental tasks is divided into two, namely through peer groups and independent independence. It can also help them develop a mature attitude towards their posture, or their self-condition (their strengths and weaknesses). Humans as creatures of God should worship God who created, so that teenagers must develop their faith and piety to God.

\section{References}

Barac, R., and Bialystok, E. (2012). Bilingual Effects on Cognitive and Linguistic Development: Role of Language, Cultural Background, and Education. Child Development, 83(2), 413-422.

Chapman, R. (2016). A Case Study of Gendered Play in Preschools: How Early Childhood Educators' Perceptions of Gender Influence Children's Play. Early Child Development and Care, 186(8), 1271-1284.

Ellis, V., and Childs, A. (2019). Innovation in Teacher Education: Collective Creativity in the Development of a Teacher Education Internship. Teaching and Teacher Education, 77, 277-286.

James, R., Dag, O., and Plaza, H. (2003). Life Span Human Development. In Population English Edition, 29. http://www.popcouncil.org/pdfs/PDRSupplements/Vol29_LifeSpan/Carey_pp1-18.pdf

Knapp, A. (1987). Optimal Development in Adolescence: What Is It and How Can It Be Encouraged? Hispanic Journal of Behavioral Sciences, 9(2), 183-205.

Marlina, D. H. (2021). Theory and Application of Developmental Psychology (D. H. Marlina (ed.)). Muhammad Zaini Publishing Foundation.

Rudd, D. (2019). Childness or Child-Less: Signs Taken for Wonders. Children's Literature in Education, 50(1), 8-22.

Saepuddin. (2019). The Concept of Character Education and Its Urgency in the Formation of a Muslim Person According to Imam Al-Ghazali. In Antimicrobial Agents and Chemotherapy, 58(12), 1-10.

Woolfolk, A. (2017). Educational Psychology (Thirteenth, Issue December). Pearson Education, Inc.

Darling-Hammond, L., Flook, L., Cook-Harvey, C., Barron, B., and Osher, D. (2020). Implications for Educational Practice of The Science of Learning and Development. Applied Developmental Science, 24(2), 97-140. 